\title{
Doctors and lawyers are different
}

"I'll never understand the medical mind." This was a lawyer talking, and I became intrigued. What could have led to such an outburst of frustration? I started thinking whether there really was a difference, as this lawyer thought, so I asked him to explain, but he knew he had already gone too far. "We'll talk later," he said, but I knew we never would.

I already knew some differences. I thought that lawyers had a goal to protect the individual from adversaries, believing in justice and liberty. It seemed to me that lawyers protect people from man-devised regulations, whereas physicians protect people from the effects of disease and trauma. It seemed that both professions had received a lot of criticism lately - physicians for not being more open, and lawyers for seeming to cause the conflicts they are supposed to settle. It also occurred to me that physicians deal mainly with what is going to happen in the future, while lawyers deal with what has already happened. I had a momentary thought that it would be nice to sort out past events at leisure, but realized this for what it was - admiring someone else's greener grass. Then I realized that it was not true. Lawyers deal with the future all the time, questioning what is the best thing to do and what is likely to happen if they proceed along a certain course of action. So, that was not a difference.

I thought this lawyer just had a bad day because he said something else to me, which gave me a clue.

"Why do doctors hedge and use whinging words?"

I know now what he meant. He needed absolute opinions because he was used to building up strong support for one side of a case, and the physician he recently spoke to used modifying words, such as 'generally' and 'probably'. So, like the physician that I am, I saw merit to both sides of the argument. The doctor meant those words, and felt that they conveyed the reality of the situation, but they were not good enough for the lawyer, who needed absolutes when absolutes would have been wrong and inaccurate, or at least wrong to testify to.

The conclusion I reached was that the search for medical truth was not like the search for justice, keeping in mind that justice happens in an adversarial system after both sides make their cases and both sides are weighed in the balance. I wondered if the difference between doctors and lawyers did not happen even earlier, back in childhood, perhaps? I wondered if most doctors want to be liked, and are simply 'nice'. Nowadays, 'nice' can be a term of derision, even meaning 'a bit boring'. I ruminated about the effects of being 'nice' when we don't really feel like it and when we would feel much better saying something subtle, but to the point; however, I realized that most of us learn that colleges are very interested in us being nice, at least when we are 'on-stage'. I wondered about the effects of being repressed, or whether the most popular and best loved doctors were those who never felt this way, or who were superb actors.

I began to think that being 'nice' would be a disadvantage for some lawyers because their job is to present one side of a case and to win by the overwhelming weight of the facts and argument. Possibly the worst thing a lawyer could be called would be 'nice'. I can imagine someone saying about a lawyer, "He's a good lawyer, but he's too nice. He would probably see the reasonableness of the other side's argument, and then they would probably settle and go out for drinks together." I can see that if you are 'nice' as a lawyer, you would want to do everything possible to prevent this from getting out. You would have to suppress it

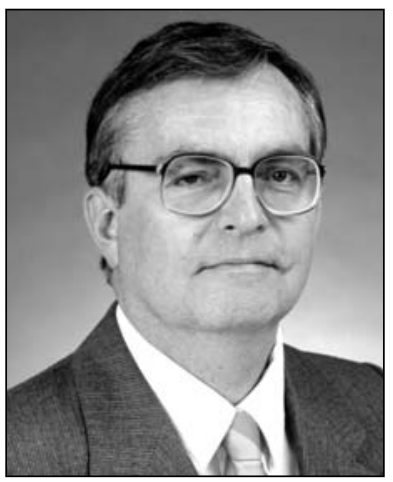

John Taylor and deny it at every turn. I can hear a lawyer saying, "Call me that once more and I'll see you in court." As a lawyer, you would have to be publicly aggressive just to keep your reputation from deteriorating. You would have to attack just to keep in practice.

Be that as it may, it is the paperwork that separates the lawyers from the doctors. Lawyers live by it, their idea being that if it is written down, it is true. To clarify, it if it is not true, why was written down? Moreover, if it is written down, it has a use. Doctors are the opposite. Paperwork is fine in its place but it gets in the way of looking after patients. There is no time for it and patients justly resent the doctor making notes instead of listening to them. Some physicians document extensively, because information is the lifeblood of diagnostic decisions. However, there is also a case to be made for not documenting too much. After all, what you do not write down cannot be used against you, and what you do write down sometimes can.

Doctors and lawyers are different, but they have much in common. I have met lawyers with such outstanding understanding of medicine and surgery that I felt ashamed for not knowing as much law in proportion, and I vowed to keep up with them. The best of both professions are alike in that they are careful of their words and the ideals of their professions. Lawyers and physicians are different in many ways, and have different views. There is no doubt that the more we know about each other's professions, the better it will be for both groups, and, particularly, for the people we serve.

John R Taylor 